\title{
The Impact of Independence on Regulatory Outcomes: the Case of EU Competition Policy
}

ARTICLE in JCMS JOURNAL OF COMMON MARKET STUDIES · APRIL 2015

Impact Factor: 1.31

DOWNLOADS

4

1 AUTHOR:

Mattia Guidi

LUISS Guido Carli, Libera Università Internazi...

11 PUBLICATIONS 0 CITATIONS

SEE PROFILE
VIEWS

2 


\title{
The Impact of Independence on Regulatory
}

\section{Outcomes: the Case of EU Competition Policy}

\author{
Mattia Guidi \\ Department of Political Science \& School of Government \\ LUISS Guido Carli, Rome
}

[Accepted for publication in JCMS: Journal of Common Market Studies, April 2015]

\begin{abstract}
Independent regulatory agencies are created in order to enhance the stability and credibility of economic regulation, and to improve policy implementation. So far, most research in political science has focused on explaining the reasons for independence, while less attention has been paid to analysing the consequences of independence. Aiming to start filling this gap, this article seeks to test if (and to what extent) independence makes a difference in competition policy enforcement. Original data on formal independence of national competition agencies in EU member states from 1993 to 2009 are employed to test if different degrees of independence (and changes in independence over time) affect foreign direct investment and consumer prices. The results indicate that the formal independence of a competition agency does not have any significant impact on either indicator, thus questioning the assumption that independence yields better regulatory performance.
\end{abstract}


Keywords: Agencies, Antitrust, Competition, Independence, Performance

\section{Introduction}

Governments worldwide are increasingly relying on "independent" agencies for performing a variety of regulatory functions (Jordana et al., 2011; Vining et al., 2014). The first input in this direction has come from a rich academic literature (see Section II) which has theorized that, in some policy domains, only bureaucrats who are not accountable to politicians can properly defend the collective interest. In addition to (and because of) that, the creation of independent agencies has been identified as a "best practice" and accordingly promoted among supranational organizations and relevant epistemic communities (see for instance OECD, 2002, 2012). However, this diffusion has occurred without an accurate assessment of the costs and benefits of "agencification". Independence is meant to improve the countries' credibility and to ensure the consistency of policy enforcement through time (see Majone, 1994, 2001; Levi-Faur, 2005; Jordana et al., 2011; Gilardi, 2008). Yet, no systematic investigation of the impact of independence on the regulatory outcome has been so far carried out (see Vining et al., 2014). Are more independent agencies better enforcers than executives or less independent agencies? Since independence implies less control of bureaucrats, and ultimately less accountability to voters (see McCubbins and Schwartz, 1984, p. 169; Gilardi, 2002, pp. 873-74), greater independence should "pay off”, yielding better regulation. Otherwise, why would delegation to independent agencies be worth recommending?

This article seeks to carry out such a test in a field that has been subject to agencification earlier and more extensively than any other in Europe: competition policy. To do so, it analyses the impact of the independence of national competition agencies (NCAs) on two proxies employed to measure their performance: foreign direct investment and consumer

prices. The results show that the formal independence of a competition agency does not have any significant impact on either indicator, thus calling into question the assumption that 
independence yields better regulatory performance

The remainder of this article proceeds as follows. Section I sums up the evolution and the current set up of EU competition policy. Section II reviews the academic literature analysing delegation to independent regulatory agencies, and its implications for the current analysis. Section III discusses how the performance of competition enforcers can be assessed. Section IV illustrates the theoretical framework from which the hypotheses to be tested are derived. In Section V, the article presents the original data on formal independence of NCAs and the other indicators employed in the empirical analysis, which is illustrated in Section VI. The last section discusses the results and concludes.

\section{Background: EU competition policy enforcement}

Among the public policies of the European Union (EU), competition (or antitrust) policy which is aimed at preventing abuses of market power or forms of collusion between undertakings - is the one in which the European Commission (and its powerful Directorate-General for Competition, DG COMP) enjoys the greatest autonomy from both EU legislators (European Parliament and Council) and member states' governments (McGowan and Cini, 1999: p. 177; Cini and McGowan, 2008; Wilks, 2005). The literature has identified several objectives of competition policy in the EU: economic welfare, integration of the internal market, the protection of consumers, the freedom to compete (Lianos, 2013; see also Cini and McGowan, 2008). Since the introduction of a European competition regime (in the Treaty of Paris, 1951, and the Treaty of Rome, 1957, and then with Council Regulation 19/62), the Commission managed to secure its control over every stage of the policy implementation and enforcement. The result has been a "common competition policy, and not just a coordinated one" (Cini and McGowan, 2008, p. 18). The scope of EU competition policy, as well as the powers of the Commission, have been constantly growing since the 1960s (Wilks, 2010; Kassim and Wright, 2009). In the field of competition policy, the Commission (and the national 
competition agencies, NCAs) can start investigations and impose sanctions, while other EU institutions and the governments of the member states have no (formal) means to intervene.

Given the importance of competition policy for European integration, it does not surprise that the Commission was given, since the very beginning, large autonomy in every stage of its enforcement - being "prosecutor, judge and jury" (McGowan and Cini, 1999, p. 190). However, this full delegation of enforcement powers had the effect of increasingly overburdening the Commission (Wilks, 2005, p. 435; Kassim and Wright, 2009, p. 752). During the 1990s, two solutions to this problem were advanced. The first was the creation of an independent European Cartel Office that would have enforced competition law in the same way the European Central Bank was meant to enforce the monetary policy of the Eurozone (Wilks and McGowan, 1995). This proposal aimed to solve not only the overload problem, but also the Commission's “overtly political approach to decision taking” (McGowan and Cini, 1999: 188; Wilks and McGowan, 1995) that many experts criticized. ${ }^{1}$ This project, however, was backed only by Germany and never met enough support to be seriously considered. An alternative solution aimed at reducing the Commission's workload was put forward by the United Kingdom first (Wilks and McGowan, 1995, p. 263) and then fully endorsed by the Commission with its 1999 "White Paper on the modernization of EU competition policy" (European Commission, 1999). This proposal suggested to decentralize antitrust enforcement, by empowering both the Commission and the NCAs to enforce EU competition policy. The argument of the Commission was that, since all the member states had developed a "culture of competition", their agencies "were now mature enough to take up the torch of implementation" (Wilks, 2005, p. 436). If the lack of national competition traditions had made it impossible to delegate enforcement to national authorities in 1962, the Europeaniza-

\footnotetext{
${ }^{1}$ This problem relates to the collegial and political nature of the Commission. Cases are prepared by the DG COMP, but then discussed and voted by all the members of the Commission (see Karagiannis, 2010, and van Waarden and Drahos, 2002, p. 917).
} 
tion of the national competition regimes (Cini and McGowan, 2008, p. 37; van Waarden and Drahos, 2002, p. 923) was now permitting a more decentralized set up.

The reform was enacted with EC Regulation 1/2003. Since $1^{\text {st }}$ May 2004, not only the Commission, but also the NCAs of the member states can fully enforce EU competition policy (see van de Gronden and de Vries, 2006). ${ }^{2}$ To facilitate coordination among all the enforcers, EU legislators established the European Competition Network (ECN), a forum which includes the DG COMP and all the NCAs. ${ }^{3}$ The ECN does not have either legal personality or formal powers: it only serves as a body for agreeing on the allocation of cases between NCAs and the Commission and for discussing strategies and best practices. Given the apparent lack of any hierarchy or formal power in the new decentralized system, competition policy scholars have shown disagreement as to its true nature. Wilks (2005) finds that the Commission has not really decentralized competition enforcement, but rather “"Europeanized' the national competition regimes" (Wilks, 2005, p. 437): the ECN would therefore be "the equivalent of a transnational agency that has gone beyond the powers of the member states to control" (Wilks, 2005: 437). On the contrary, Kassim and Wright (2009) argue that the 2003 reform was the response to increasing pressures from the epistemic community of competition policy experts, that is a response to the overload problem and to the need for a more flexible case management system.

The decentralization, however, raises the question of how a policy can be uniformly enforced by very different institutional actors. Indeed, NCAs in EU member states enjoy very different degrees of formal independence from the respective national political authorities. How does this influence their performance? Is this independence ultimately needed? The empirical puzzle that EU competition policy poses is, put simply, whether the independence

\footnotetext{
${ }^{2}$ Until then, NCAs had the power to sanction cartels but not to grant exemptions ex Art. 101(3).

${ }^{3}$ Other similar networks have been created also in the fields of finance, energy and telecommunication (see Maggetti, 2014).
} 
of the enforcers matters or not. No EU regulation or directive explicitly mentions independence as a requirement for NCAs, nor does it the Commission's White Paper of 1999. So, the Commission has not always consistently advocated for NCAs independence in the past. On the other hand, a rich body of scholarly literature (see following section) claims indeed that independence matters, and it seems that the DG COMP itself has recently become more attentive to this issue. ${ }^{4}$ Which view is correct, then? If independence matters, why is not the Commission more explicit in recommending it? Vice versa, if it does not matter, should we conclude that scholars, practitioners, organizations that have promoted "agencification" in the last decades were overconfident about the power and impact of regulatory autonomy? This study seeks to adjudicate this dispute.

\section{Causes and consequences of independence}

Competition agencies have spread all over Europe (and in the rest of the world) between the mid 1980s and the early 2000s (Wilks and Bartle, 2002, p. 149), following a trend of "agencification" that has characterized both advanced and developing economies (Jordana et al., 2011; Coen and Thatcher, 2005; Gilardi, 2005, 2008; Levi-Faur, 2005). Empirical evidence indicates that regulatory agencies have "become the 'appropriate' model of governance in capitalist economies" (Jordana et al., 2011, p. 1344) and that their establishment has followed a pattern of "diffusion" across countries and sectors (Jordana et al., 2011, p. 1356). The literature on regulatory agencies has identified several factors explaining the delegation of policy enforcement to non-majoritarian institutions.

It has been argued that politicians resort to creating independent agencies when they need to reassure economic actors that they will implement consistently through time a certain pol-

\footnotetext{
${ }^{4}$ See the speech delivered in Vienna by Director-General for Competition Italianer on 12 December 2014: http://ec.europa.eu/competition/speeches/text/sp2014_08_en.pdf.
} 
icy choice (Majone, 1996, 1999, 2001; empirical tests can be found in Gilardi, 2002, 2008; Elgie and McMenamin, 2005; Wonka and Rittberger, 2010; Guidi, 2014). The act of delegation to an agency, which is given the power to take decisions that once were left to the government, serves as a signal of credible commitment. The government imposes a high cost on a future decision of reneging on its promise, thus making it more unlikely. Like delegation of monetary policy to central banks is aimed at making a certain inflation target credible (see among others Kydland and Prescott, 1977; Barro and Gordon, 1983; Rogoff, 1985), delegation to IRAs is aimed at making other targets - for instance, the state's commitment to fair competition - credible. Other contributions (Moe, 1990; for empirical tests see Gilardi, 2008; Wonka and Rittberger, 2010; Guidi, 2014) do not assume politicians to be interested in granting credibility through time, but simply in protecting their policy choices from future majorities that could overturn them. However, these authors too maintain that the effect of IRAs is that of insulating policy implementation from the influence of alternating governments. Scholars have also emphasized the need for expertise that arises "in informationally intense issue areas" (Franchino, 2004, p. 274), in which politicians do not possess enough knowledge and ability to formulate sound and effective policies (Bawn, 1995; Majone, 1996; Epstein and O’Halloran, 1999; Franchino, 2004). Another often cited reason for delegating to IRAs is that those who are in charge of taking unpopular decisions find it convenient to delegate these tasks to bodies that are perceived as separated from them. IRAs would let politicians avoid the blame for choices that create winners and losers, whose blame would be thus addressed to bureaucrats (Fiorina, 1982; Thatcher, 2002; Wilks and Bartle, 2002).

The literature has also identified other determinants of agency independence that do not strictly relate to the policy-makers' goals, but rather to the political and economic environment in which agencies are established. In particular, several empirical studies have found that veto players (the number of actors whose agreement is necessary for a change of the status quo in a political system) may have a twofold effect: one the one hand, they can be 
perceived as "stabilizers" of the policy output, and therefore make delegation to an independent agency less necessary (Gilardi, 2008); on the other, a high number of veto players can be a precondition for credible delegation, as it signals that it will be difficult to return to the previous institutional arrangement (Moser, 1999; Keefer and Stasavage, 2003). Finally, some recent contributions have highlighted that also the "variety of capitalism" is a determinant of agency independence. In particular, liberal market economies tend to rely on IRAs more than coordinated market economies (Guardiancich and Guidi, 2015). As for national competition agencies, Guidi (2014) finds that countries with intermediate degrees of coordination, being less capable of efficiently allocating capital and labour force, tend to have more independent competition authorities than those of liberal and coordinated market economies, in order to compensate for their perceived economic inefficiency.

Besides the explanation of why agencies are more or less independent, less attention has been paid to the consequences of agency independence - with the exception of central bank independence, whose impact on inflation has been thoroughly studied (Grilli et al., 1991; Cukierman et al., 1992; Giavazzi and Pagano, 1988; Alesina and Summers, 1993; Franzese, 1999). The literature on the consequences of agency independence on policy output, in fact, is still in its infancy and mainly based on case studies (Verhoest, 2005; Verhoest et al., 2010; Busuioc et al., 2012; a more rigorous and comparative study is that of Maggetti, 2009). Although some studies on agencification in public service provision have proved that managerial autonomy increases performance in the short term (see Vining et al., 2014, pp. 11-12), and although the impact of enforcement on business practices has been shown in various fields (see e.g. Jappelli et al., 2005; Fairman and Yapp, 2005; Gathmann, 2008), for many types of regulatory agencies, included NCAs, no empirical work of this kind has been done.

NCAs in the EU are an interesting case to study in this respect, for three main reasons. First, empirical studies on antitrust enforcement have so far been rare (but see McChesney and Shughart, 1995). Second, since NCAs in the EU have been empowered to enforce not 
only national, but also EU competition law, and given the centrality of competition policy for the functioning of the Single Market and of the Economic and Monetary Union, it is crucial to ascertain whether NCAs' independence has an impact on competition enforcement. Third, NCAs in the EU represent a rather unique sample of differently independent regulators that enforce very similar policies. Significant differences in their regulatory outcome are most unlikely to be due to differences in the legislation, and should instead point to different regulatory capabilities and practices.

\section{How to measure performance}

What is (or what should be) the link between formal independence and performance? More specifically, how can a competition agency be proven successful? A first choice that must be made is that between measuring NCAs' policy output and their policy outcome. By policy output I mean the practical actions and activities carried out by the authorities, i.e. (i) investigations started to collect information on possible competition law violations; (ii) decisions on these violations, which may include sanctions and/or commitments that firms are required to accept; (iii) decisions on mergers. By policy outcome I mean the effect that the NCAs' activity has on the economy, the market and the behaviour (and perceptions) of market actors. Both approaches have advantages and drawbacks.

The main advantage of measuring the policy output is that information on investigations and decisions is quite easy to collect - almost all authorities provide it on their annual reports. However, the simplicity of this measurement comes with several shortcomings. The first is that not all NCAs record this information uniformly. For instance, some count as "investigations" even brief procedures that are opened after receiving complaints and closed almost immediately after, while others do not. Also, while all authorities report infringement decisions (that is, decisions closed with some sort of sanction), there is less uniformity as regards decisions closed with "commitments", when the NCA closes the procedure without issuing 
any sanction, but at the same time the firm commits to change one or more practices that were likely to be sanctioned by the agency. Even more problematic are the effects of NCAs' "leniency programmes", which grant exemptions from fines (or fine reductions) to whistle blowers. These procedures, to be effective, must be carried out with some confidentiality, which further complicates the measurement of NCAs' activity. Another problem related to measuring policy output is that, even if one managed to collect information on all acts for all agencies, it would not be possible to weigh the impact of each decision. One important decision issued against a multinational firm certainly has a higher impact on the economy than 20 decisions against small competition infringements. Still, unless one assesses the impact of all decisions one by one (a virtually impossible task), all decisions should be assigned the same weigh. Finally, a quantitative measurement of investigations and decisions would not allow to assess the impact of the creation of a NCA, because only the activities of already established agencies could be compared. This would severely reduce the number of available cases to be analysed.

Measuring the policy outcome does not have such limitations. More cases and years can be used in the empirical analysis, and, what is more, the effect of the establishment of a NCA can be assessed, because it is possible to code the absence of a NCA as "zero independence". Moreover, this approach fits better the purpose of this article, which is to test the "credibility effect" yielded by independent regulatory agencies. Credibility is an "immaterial" good, which is supposed to have an impact independently from the practical activity of a body. That said, measuring the policy outcome of NCAs is problematic because it is not simple to identify the variable(s) on which independence should have an impact: "competition" is an ubiquitous concept. The next section seeks to address this issue. 


\section{Theory and hypotheses}

Before putting forward hypotheses to be tested, let us consider the assumptions that inform the theoretical model presented in this article. First of all, this study assumes that politicians have mixed incentives as regards competition policy. They are in favour of competition because they think it can boost growth, but at the same time they know that not everyone wins from competition: national firms that are not competitive and their employees can be damaged by a strict competition enforcement, and politicians may be tempted to avoid such consequences. The second assumption is that firms and private economic actors invest in a country if they are reasonably convinced that the political authorities of that country will not favour national firms. Thirdly, international investors know that, even if politicians commit to avoid any interference in the economy, various electoral incentives can lead them to renege on their promises.

More specifically, a potential foreign investor invests in a country if she or he is confident that its investment at $t_{0}$ will not be disfavoured at $t_{1}$. Although Art. 107 of the Treaty on the Functioning of the European Union prohibits state aid, a national government could favour a "relaxed" enforcement of competition policy that aims at not punishing abuses of dominant position or unlawful agreements between national firms. Let us consider that, although the Commission can in theory enforce EU competition policy in all countries (thus making the national government's attitude irrelevant), in practice it is not able to do so (see Section I). Therefore, the competition enforcement carried out by national authorities has an impact on the decisions of international investors. The only way in which a government can make international investors trust its country is by delegating competition enforcement to a body, the NCA, that it cannot control. The more the NCA is independent from the government, the less likely it is that it will be influenced by its preferences when enforcing competition policy. Let us bear in mind that an independent NCA has no connection with the electoral cycle, and 
therefore no incentive to follow the government's preferences for a less strict competition enforcement: an independent NCA maximizes its reputation, not the political principal's utility (Majone, 1996, p. 6).

Thus, the first hypothesis to be tested is the following:

H1: The more a country's NCA is independent, the more that country will be attractive for international investors

As regards another clear goal of competition policy, consumer protection (see Section I), a similar logic should apply. If competition is not distorted, prices for a given quantity of goods or services are determined by the intersection between the demand and supply curves. Vice versa, monopolies, abuses of dominant positions and cartels all aim at extracting rents, fixing prices higher than the equilibrium value. Not all firms have an incentive to do so, of course. Yet, for undertakings that may find it convenient to extract monopolistic rents or to collude with competitors, the likelihood of a strict competition enforcement should matter (for an example of the influence of policy enforcement on economic actions see for instance Jappelli et al., 2005). Similarly to the case of foreign investments, politicians might not be incline to fight these practices if they do not have an electoral incentive to do so. But in the same fashion as above, tying their own hands can be a credible signal that they will not exert any influence in competition enforcement. Therefore:

H2: The more a country's NCA is independent, the lower will be its general price level

\section{Data and operationalization}

As regards the dependent variables, the two hypotheses presented in the previous section posit that independence should have a positive impact on foreign investments and a negative impact on consumer prices. Hence, I choose to test the impact of independence on two indicators: (i) the amount of foreign direct investment as a percentage of GDP, which is a proxy for a 
country's ability to attract investors vis-à-vis other countries; ${ }^{5}$ (ii) the consumer price index, a proxy for the NCAs' effectiveness in granting low prices. ${ }^{6}$

The main explanatory variable is the formal independence of NCAs in all EU member states $^{7}$ from $1993^{8}$ to 2009 (Guidi, 2014). Data on all the known features of the agencies' formal independence have first been collected with a web survey, filled out by NCAs' officers in September-December 2009 (see Appendix I). That survey, providing information on the formal independence of NCAs as of 2009, was then integrated with email inquiries to NCAs' officers between July 2010 and September 2011, and searches on the authorities' web sites and other sources carried out in October-November 2013. The aim of this supplementary search was to trace all the changes occurred in the agencies' statutes from 1993 (or from their creation) to 2009. This data collection allows one to have 27 values of NCAs' independence (one for each country) for 16 years, which amounts to 432 "observations". The independence index was derived from the scores of a factor analysis run on a dataset of 34 indicators of independence for each country in each year. The index was rescaled to range between 0 and 1: 0 is the absence of any independent agency, 1 is the maximum independence. As we can see in Figure 1, there has been a general increase in formal independence over time, caused by both $i$ ) the establishment of competition agencies in countries where no agency was present and $i$ ) the increasing independence that has been granted in several cases to already existing NCAs. Figure 1 also shows that cross-country variation has been constantly decreasing, and

${ }^{5}$ Foreign direct investment, net inflows (BoP, current US\$), retrieved from http://databank.worldbank.org on 12 February 2014.

6 Inflation, consumer prices (annual \%), World Development Indicators, retrieved from http://data.worldbank.org/data-catalog/world-development-indicators on 4 May 2014

${ }^{7}$ The countries included are the 27 member states as of 2009, thus excluding Croatia.

${ }^{8}$ Although data from 1990 has been collected, 1993 has been chosen as the starting date because it is the first year in which all the countries included in the sample existed (the last being Czech Republic and Slovakia, which are independent states since the $1^{\text {st }}$ January 1993). 
it is substantially stable since 2004, when Regulation 1/2003 has entered into force.

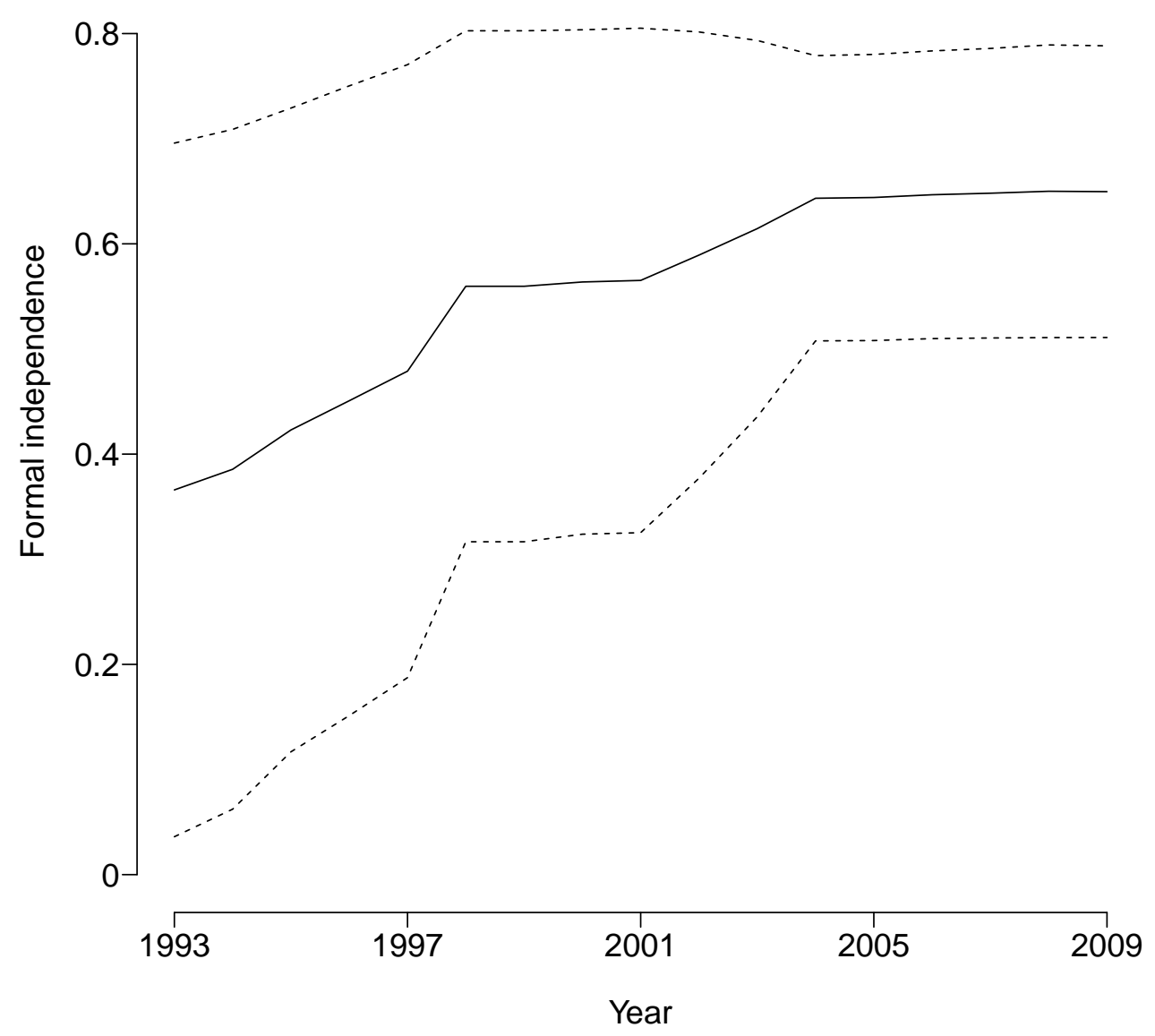

Fig. 1: Average formal independence of NCAs (1993-2009). Dashed lines denote the 95\% confidence interval.

Some words need to be said about the choice of focusing on formal rather than on actual independence. Although scholars have attempted to measure actual (or de facto) independence in addition to - or in contrast with - formal independence (see Maggetti, 2007, 2012; Hanretty and Koop, 2013), there are two reasons for which this study focuses only on the latter. First, this article aims at testing the impact of legislative measure on policy output: legislation is the main "variable" that politicians use, and it is important to ascertain whether it has an impact per se. Second, this analysis wants to apply to NCAs the same logic applied 
to central banks when testing if their statutory independence has an impact on the inflation rate: using the same explanatory variable (formal, or statutory, independence) can help to meaningfully compare the impact of such type of delegation in two distinct, albeit related, policy fields.

In a statistical analysis of this kind one must also control for other factors that are likely to influence the response variables. In particular, this study employs a set of economic controls and a set of institutional and political controls. Among the economic controls, the following indicators are taken into account: lending interest rate, ${ }^{9}$ government expenditure as a percentage of GDP, ${ }^{10}$ debt-to-GDP ratio, ${ }^{11}$ government bond yields, ${ }^{12}$ GDP growth, ${ }^{13}$ change in labour productivity. ${ }^{14}$ As all these indicators are related to economic development, state intervention in the economy and sustainability of public debt, they are all likely to affect the variation in the dependent variables. Among the institutional and political controls, the variables included in the analysis are: EU membership, ${ }^{15}$ Euro membership, ${ }^{16}$ the entry into force of Regulation $1 / 2003,{ }^{17}$ party orientation of the executive, ${ }^{18}$ parliamentary control

\footnotetext{
${ }^{9}$ World Bank data, retrieved from http://data.worldbank.org/indicator/FR.INR.LEND on 13 February 2014.
}

${ }^{10}$ Eurostat data, retrieved from http://epp.eurostat.ec.europa.eu/ on 4 April 2014.

${ }^{11}$ Eurostat data, retrieved from http://epp.eurostat.ec.europa.eu/ on 14 February 2014.

12 Eurostat data, retrieved from http://epp.eurostat.ec.europa.eu/ on 3 March 2014.

${ }^{13}$ Eurostat data, retrieved from http://epp.eurostat.ec.europa.eu/ on 12 February 2014.

${ }^{14}$ Eurostat data, retrieved from http://epp.eurostat.ec.europa.eu/ on 3 March 2014.

15 A dummy variable, coded as 1 if a country was member of the EU in a given year and 0 otherwise.

16 A dummy variable, coded as 1 if a country was member of the single currency in a given year and 0 otherwise.

17 Regulation 1/2003 entered into force, for all EU members, on the 1st May of 2004. All countries are coded as 1 from 2005 on, 0 otherwise.

18 Variable "execrlc" from the Database of Political Institutions (DPI, Beck et al., 2001, see the codebook at http://siteresources.worldbank.org/INTRES/Resources/469232-1107449512766/DPI2012_Codebook2.pdf), 
by the government, ${ }^{19}$ percentage of seats for the government majority in the parliament ${ }^{20}$ plurality electoral system, ${ }^{21}$ proportional representation, ${ }^{22}$ tenure of the democratic system, ${ }^{23}$ number of veto players, ${ }^{24}$ polarization, ${ }^{25}$ degree of decentralization. ${ }^{26}$ These indicators seek to measure government preferences, government stability and efficiency of decision-making, all factors that may affect the propensity to invest in a country and the competitiveness of its economy. 
Tab. 1: Random effects panel regression models

\begin{tabular}{|c|c|c|c|c|c|c|}
\hline & \multicolumn{6}{|c|}{ Dependent variables: } \\
\hline & \multicolumn{3}{|c|}{ Foreign direct investment $t^{\ddagger}$} & \multicolumn{3}{|c|}{ Consumer price index ${ }^{\ddagger}$} \\
\hline & (1) & (2) & (3) & (4) & $(5)$ & (6) \\
\hline Formal independence & $\begin{array}{c}0.035 \\
(0.077)\end{array}$ & $\begin{array}{c}0.067 \\
(0.086)\end{array}$ & $\begin{array}{c}0.060 \\
(0.082)\end{array}$ & $\begin{array}{c}0.046 \\
(0.167)\end{array}$ & $\begin{array}{l}-0.206 \\
(0.207)\end{array}$ & $\begin{array}{l}-0.073 \\
(0.217)\end{array}$ \\
\hline Lending interest rate ${ }^{\ddagger}$ & $\begin{array}{c}0.001 \\
(0.010)\end{array}$ & & $\begin{array}{c}0.002 \\
(0.011)\end{array}$ & $\begin{array}{c}0.044 \\
(0.042)\end{array}$ & & $\begin{array}{c}0.028 \\
(0.040)\end{array}$ \\
\hline Government expenditure & $\begin{array}{c}-0.0004 \\
(0.001)\end{array}$ & & $\begin{array}{c}0.001 \\
(0.002)\end{array}$ & $\begin{array}{c}-0.017^{*} \\
(0.011)\end{array}$ & & $\begin{array}{c}-0.036^{*} \\
(0.020)\end{array}$ \\
\hline Debt (\% GDP) & $\begin{array}{l}-0.0001 \\
(0.0005)\end{array}$ & & $\begin{array}{c}-0.0002 \\
(0.001)\end{array}$ & $\begin{array}{l}-0.001 \\
(0.003)\end{array}$ & & $\begin{array}{l}-0.004 \\
(0.006)\end{array}$ \\
\hline Bond yields $(\log )$ & $\begin{array}{l}-0.041 \\
(0.031)\end{array}$ & & $\begin{array}{l}-0.032 \\
(0.041)\end{array}$ & $\begin{array}{c}0.424 \\
(0.274)\end{array}$ & & $\begin{array}{c}0.394 \\
(0.244)\end{array}$ \\
\hline GDP growth & $\begin{array}{c}0.001 \\
(0.004)\end{array}$ & & $\begin{array}{c}0.001 \\
(0.003)\end{array}$ & $\begin{array}{l}0.067^{* *} \\
(0.031)\end{array}$ & & $\begin{array}{l}0.056^{*} \\
(0.029)\end{array}$ \\
\hline Labour productivity change ${ }^{\ddagger}$ & $\begin{array}{l}-0.001 \\
(0.017)\end{array}$ & & $\begin{array}{c}0.001 \\
(0.015)\end{array}$ & $\begin{array}{l}-0.088 \\
(0.073)\end{array}$ & & $\begin{array}{c}-0.125^{*} \\
(0.070)\end{array}$ \\
\hline EU membership & & $\begin{array}{c}0.027 \\
(0.025)\end{array}$ & $\begin{array}{c}0.029 \\
(0.029)\end{array}$ & & $\begin{array}{c}0.054 \\
(0.178)\end{array}$ & $\begin{array}{l}-0.034 \\
(0.206)\end{array}$ \\
\hline Euro membership & & $\begin{array}{l}-0.010 \\
(0.020)\end{array}$ & $\begin{array}{l}-0.012 \\
(0.031)\end{array}$ & & $\begin{array}{l}-0.032 \\
(0.195)\end{array}$ & $\begin{array}{c}0.040 \\
(0.190)\end{array}$ \\
\hline Reg 1/2003 & & $\begin{array}{l}0.0004 \\
(0.019)\end{array}$ & $\begin{array}{l}-0.009 \\
(0.023)\end{array}$ & & $\begin{array}{c}0.193 \\
(0.143)\end{array}$ & $\begin{array}{l}0.378^{*} \\
(0.209)\end{array}$ \\
\hline Left-wing government & & $\begin{array}{c}0.005 \\
(0.006)\end{array}$ & $\begin{array}{c}0.004 \\
(0.006)\end{array}$ & & $\begin{array}{l}-0.017 \\
(0.040)\end{array}$ & $\begin{array}{l}-0.014 \\
(0.042)\end{array}$ \\
\hline Gov't control of all houses & & $\begin{array}{l}-0.021 \\
(0.019)\end{array}$ & $\begin{array}{l}-0.021 \\
(0.021)\end{array}$ & & $\begin{array}{c}0.408 \\
(0.254)\end{array}$ & $\begin{array}{c}0.430 \\
(0.324)\end{array}$ \\
\hline Seats percentage gov't coalition & & $\begin{array}{c}0.014 \\
(0.097)\end{array}$ & $\begin{array}{c}0.016 \\
(0.101)\end{array}$ & & $\begin{array}{c}0.223 \\
(0.534)\end{array}$ & $\begin{array}{c}0.083 \\
(0.557)\end{array}$ \\
\hline Plurality electoral system & & $\begin{array}{c}-0.029^{*} \\
(0.017)\end{array}$ & $\begin{array}{l}-0.024 \\
(0.020)\end{array}$ & & $\begin{array}{l}-0.110 \\
(0.249)\end{array}$ & $\begin{array}{c}0.085 \\
(0.275)\end{array}$ \\
\hline Proportional representation & & $\begin{array}{c}0.030 \\
(0.067)\end{array}$ & $\begin{array}{c}0.037 \\
(0.091)\end{array}$ & & $\begin{array}{l}-1.261 \\
(1.036)\end{array}$ & $\begin{array}{l}-1.386 \\
(1.419)\end{array}$ \\
\hline Democratic tenure & & $\begin{array}{c}0.001 \\
(0.001)\end{array}$ & $\begin{array}{c}0.001 \\
(0.002)\end{array}$ & & $\begin{array}{c}-0.046^{* * *} \\
(0.017)\end{array}$ & $\begin{array}{c}-0.051^{*} \\
(0.027)\end{array}$ \\
\hline Veto players & & $\begin{array}{l}-0.006 \\
(0.008)\end{array}$ & $\begin{array}{l}-0.006 \\
(0.008)\end{array}$ & & $\begin{array}{l}-0.034 \\
(0.037)\end{array}$ & $\begin{array}{l}-0.045 \\
(0.040)\end{array}$ \\
\hline Polarization & & $\begin{array}{l}-0.007 \\
(0.012)\end{array}$ & $\begin{array}{l}-0.008 \\
(0.012)\end{array}$ & & $\begin{array}{c}0.098 \\
(0.080)\end{array}$ & $\begin{array}{c}0.091 \\
(0.096)\end{array}$ \\
\hline Autonomous regions & & $\begin{array}{l}-0.030 \\
(0.028)\end{array}$ & $\begin{array}{l}-0.027 \\
(0.026)\end{array}$ & & $\begin{array}{c}0.078 \\
(0.187)\end{array}$ & $\begin{array}{c}0.281 \\
(0.230)\end{array}$ \\
\hline Constant & $\begin{array}{c}0.123 \\
(0.089)\end{array}$ & $\begin{array}{l}-0.009 \\
(0.106)\end{array}$ & $\begin{array}{c}0.026 \\
(0.154)\end{array}$ & $\begin{array}{c}0.577 \\
(0.477)\end{array}$ & $\begin{array}{l}3.733^{* *} \\
(1.533)\end{array}$ & $\begin{array}{l}4.853^{* *} \\
(2.244)\end{array}$ \\
\hline Observations & 432 & 432 & 432 & 432 & 432 & 432 \\
\hline Adjusted $\mathrm{R}^{2}$ & 0.093 & 0.094 & 0.109 & 0.512 & 0.385 & 0.448 \\
\hline F Statistic & $6.059 * *$ & 3.500 & 2.848 & $59.175^{* * *}$ & $19.840 * * *$ & $18.414 * * *$ \\
\hline
\end{tabular}

Note: Random effects panel regression with individual effects and heteroscedasticity-consistent standard errors.

Pooled estimates and standard errors calculated from 50 multiply imputed datasets with Rubin's (1987) formula.

Variance components estimated with Amemiya (1971) procedure. Variables with $\ddagger$ are arcsine transformed. Lagged dependent variable included in both models. Estimates' significance: ${ }^{*} \mathrm{p}<0.1 ;{ }^{*} \mathrm{p}<0.05 ;{ }^{* * *} \mathrm{p}<0.01$. 


\section{Statistical analysis}

The two hypotheses presented in Section III are tested with a random effects regression model (see Table 1), ${ }^{27}$ formulated as:

$$
y_{i t}=x_{i t}^{\prime} \beta+\alpha+u_{i}+\varepsilon_{i t}
$$

where $y_{i t}$ is the value of either response variable (ratio of foreign direct investment to GDP or consumer price index) of country $i$ in year $t, x_{i t}^{\prime}$ is the set of regressors for each coutry and year with their coefficients $\beta, \alpha$ is a constant term, $u_{i}$ is a country specific random element and

retrieved on 14 January 2013. The variable codes the "[p]arty orientation with respect to economic policy", 1 if right, 2 if centre, 3 if left.

${ }^{19}$ Whether or not the government has "an absolute majority in the houses that have lawmaking powers", variable "allhouse" in the DPI.

${ }^{20}$ The number of seats for the government majority (variable "numgov" in the DPI) divided by the total number of seats (variable "totalseats" in the DPI).

${ }^{21}$ A dummy variable (variable "plurality" in the DPI), coded as 1 if "legislators are elected using a "winnertakes-all' / 'first past the post' rule", 0 otherwise.

${ }^{22}$ A dummy variable (variable "pr" in the DPI), coded as 1 "candidates are elected based on the percent of votes received by their party", 0 otherwise.

${ }^{23}$ Variable "tensys" in the DPI, measuring how many years "the country been autocratic or democratic". In the sample used in this analysis, all countries are democracies.

${ }^{24}$ Variable "checks" (Keefer and Stasavage, 2003) in the DPI.

${ }^{25}$ Variable "polariz" in the DPI, measuring the "[m]aximum polarization between the executive party and the four principle parties of the legislature".

${ }^{26}$ A dummy variable (variable "auton" in the DPI), coded as 1 if the country has autonomous regions or sub-national units, 0 otherwise.

${ }^{27}$ The regression models in Table 1 have been performed with the package plm (Croissant and Millo, 2008) in R (R Core Team, 2013). 
$\varepsilon_{i t}$ is the error term (see Greene, 2012, p. 347). According to the statistical tests performed, the random effects model seems preferable both to the fixed effects one and to pooled ordinary least squares regression. ${ }^{28}$ Some variables have been transformed in order to reduce their skewness and kurtosis: bond yields has been log transformed, while foreign direct investment to GDP, consumer price index, lending interest rate and labour productivity change have been arcsine transformed (because they have both negative and positive values). ${ }^{29}$ With such a large predictor matrix (Models 3 and 6 have 21 regressors) even a modest percentage of missing values $(4.2 \%)$ can lead to delete too many useful observations. To overcome this problem, missing values have been replaced with multiply imputed ones. ${ }^{30}$ To reduce serial correlation, lagged dependent variables have been included in all models.

For each dependent variable, the regression has first been run including the economic controls only (Models 1 and 4), then including the institutional controls only (Models 2 and 5), and finally including all controls (Models 3 and 6). With all the different specifications, the results of the two models are consistent. Finally, both models display some degree of heteroscedasticity. For this reason, robust standard errors have been computed and are displayed in Table 1. Robust standard errors for both models do not significantly differ from the "classical" ones, thus indicating that we do not face any mis-specification problem (see King and Roberts, 2014).

${ }^{28}$ A Hausman test (Hausman, 1978) has been performed for all the models, comparing the random effects with the fixed effects model. In all cases, the null hypothesis is confirmed, meaning that the coefficients of the two models do not differ systematically - and, therefore, that the random effects model is preferable (see Greene, 2012, p. 379).

${ }^{29}$ D'Agostino and Anscombe-Glynn normality tests have been performed on all the transformed and original variables, showing that in all cases the transformation significantly reduces the skewness and kurtosis of the distribution.

${ }^{30}$ Fifty datasets have been imputed using the package Amelia I I (Honaker et al., 2011) in R. The regression analysis has then been performed on every imputed dataset. 


\section{Discussion of results and conclusions}

Both $\mathrm{H} 1$ and $\mathrm{H} 2$ do not appear to be confirmed by the empirical analysis: the independence of NCAs does not have a significant impact on either foreign direct investment or consumer price index. Regarding the first hypothesis, there is no clear evidence that countries without a competition agency (that is, with NCA independence $=0$ ) receive, on average, less foreign direct investment than countries with a competition agency scoring higher in the independence index. This also means that countries increasing the independence of their competition agency over time do not experience, all else equal, a significant increase in foreign direct investment. In general, no variable is significant in Models 1, 2 and 3: not only the formal independence of NCAs, but also the economic and institutional control variables fail to account for variations in foreign direct investment.

In Models 4, 5 and 6 as well, the variation in the consumer price index is not explained by NCAs' independence. In these models, however, several control variables appear to have a significant impact on prices. Consumer prices are positively affected, among others, by GDP growth, and negatively by government expenditure and increases in labour productivity. It is interesting to note that the overall explanatory power of Models 4,5 and 6 is much higher than that of the first three models. The economic and institutional controls are more effective in predicting the variation in the consumer price index than they are in predicting the variation of foreign direct investment. In other words, the consumer price index appears to be more correlated than the percentage of foreign direct investment to GDP with the other economic, institutional and political indicators.

Despite a considerable body of (academic and policy-oriented) literature suggesting that independence should improve regulatory outcomes, this study points to a lack of evidence for such effect, at least as far the indicators here considered are concerned. The hypotheses formulated in this study assumed that independence yielded a "credibility effect" that would 
be recognized by market actors, when deciding where to invest and whether or not to collude. The lack of empirical support for the hypotheses calls for further investigation. It is indeed crucial to understand why formal independence is not considered by market actors, and what is considered instead. Regarding H1, ad-hoc surveys or interviews can help explain what investors look at. Assuming that they disregard formal independence, it is possible that they decide solely on the basis of other factors on which NCAs' independence has no impact. On the other hand, investors might still take NCAs into consideration, but looking more at what we generally label as de facto independence (see Section V above): the "self-determination of agencies' preferences, and their autonomy throughout the use of regulatory competencies" (Maggetti, 2007, p. 272) might be more important than statutory rules giving on paper more or less leeway to competition agencies.

Also the lack of confirmation for $\mathrm{H} 2$ invites some reflection. The "credibility effect" does not seem to work for discouraging abuses of dominant positions or cartels either. Besides what has been said about the perceptions of investors, this finding can probably be explained also with the little impact that potential violations of antitrust policy have in the mechanism of price formation. While in the case of foreign direct investment the total is made of a relatively small amount of single investment decisions, consumer prices are the result of billions of decentralized economic transactions. Even if there is an impact on firms in concentrated sectors that can benefit from violations of competition policy, their weight in the economy is probably too limited to be detected.

With regard to the implementation of EU competition policy in the member states, the findings of this article seem to exclude that the different degrees of independence of NCAs may jeopardize its enforcement: if formal independence does not affect the behaviour of market actors, we can expect that all European NCAs will enjoy the same credibility vis-àvis economic actors at home. At the same time, it becomes crucial to investigate if other outcomes (or outputs) of NCAs' activities are affected by their institutional set-up. And if 
independence did not change anything, should it still be recommended?

In conclusion, the empirical evidence documented in this article suggests that, as far as competition policy is concerned, it is time to critically revise the conventional wisdom about the benefits of agency independence. Competition has been one of the first regulatory policies to be delegated to non-majoritarian institutions (with the Federal Trade Commission in the US in 1914, and then the Bundeskartellamt in Germany in 1958 and the Office of Fair Trading in the UK in 1973), and NCAs in Europe are nowadays strongly legitimized by the expansion of EU competition policy. However, for non-elected bodies, legitimacy also depends on regulatory outcomes. Independence from politics means, above all, independence from voters, and it is fully justified only in view of improved policy-making. Determining the real impact of agency independence can help us understand to what extent regulatory autonomy is still worth recommending in this field.

\section{References}

Alesina, A. and Summers, L.H. (1993) 'Central Bank Independence and Macroeconomic Performance: Some Comparative Evidence'. Journal of Money, Credit and Banking, Volume 25, No. 2, pp. 151-162.

Amemiya, T. (1971) 'The Estimation of the Variances in a Variance-Components Model'. International Economic Review, Volume 12, No. 1, pp. 1-13.

Barro, R.J. and Gordon, D.B. (1983) 'Rules, discretion and reputation in a model of monetary policy'. Journal of Monetary Economics, Volume 12, No. 1, pp. 101-121.

Bawn, K. (1995) 'Political Control Versus Expertise: Congressional Choices about Administrative Procedures'. The American Political Science Review, Volume 89, No. 1, pp. 62-73.

Beck, T., Clarke, G., Groff, A., Keefer, P. and Walsh, P. (2001) 'New Tools in Comparative Political 
Economy: The Database of Political Institutions'. World Bank Economic Review, Volume 15, No. 1, pp. $165-176$.

Busuioc, M., Groenleer, M. and Trondal, J. (eds.) (2012) The agency phenomenon in the European Union: emergence, institutionalisation and everyday decision-making, European policy Research Unit series (Manchester; New York: Manchester University Press; Palgrave Macmillan).

Cini, M. and McGowan, L. (2008) Competition policy in the European Union, European Union series, 2nd edition (New York: Palgrave Macmillan).

Coen, D. and Thatcher, M. (2005) 'The New Governance of Markets and Non-Majoritarian Regulators'. Governance, Volume 18, No. 3, pp. 329-346.

Croissant, Y. and Millo, G. (2008) 'Panel Data Econometrics in R: The plm Package'. Journal of Statistical Software, Volume 27, No. 2.

Cukierman, A., Webb, S.B. and Neyapti, B. (1992) 'Measuring the Independence of Central Banks and Its Effect on Policy Outcomes'. The World Bank Economic Review, Volume 6, No. 3, pp. 353-398.

Elgie, R. and McMenamin, I. (2005) 'Credible Commitment, Political Uncertainty or Policy Complexity? Explaining Variations in the Independence of Non-majoritarian Institutions in France'. British Journal of Political Science, Volume 35, No. 3, pp. 531-548.

Epstein, D. and O’Halloran, S. (1999) Delegating Powers: A Transaction Cost Politics Approach to Policy Making Under Separate Powers (New York: Cambridge University Press).

European Commission (1999) 'White paper on modernisation of the rules implementing articles 85 and 86 of the EC Treaty', Commission Programme No 99/027.

Fairman, R. and Yapp, C. (2005) 'Enforced Self-Regulation, Prescription, and Conceptions of Compliance within Small Businesses: The Impact of Enforcement*'. Law \& Policy, Volume 27, No. 4, pp. $491-519$. 
Fiorina, M.P. (1982) 'Legislative choice of regulatory forms: Legal process or administrative process?'. Public Choice, Volume 39, No. 1, pp. 33-66.

Franchino, F. (2004) 'Delegating Powers in the European Community'. British Journal of Political Science, Volume 34, No. 2, pp. 269-293.

Franzese, R.J. (1999) 'Partially Independent Central Banks, Politically Responsive Governments, and Inflation'. American Journal of Political Science, Volume 43, No. 3, pp. 681-706.

Gathmann, C. (2008) 'Effects of enforcement on illegal markets: Evidence from migrant smuggling along the southwestern border'. Journal of Public Economics, Volume 92, No. 10-11, pp. 19261941.

Giavazzi, F. and Pagano, M. (1988) 'The advantage of tying one's hands: EMS discipline and Central Bank credibility'. European Economic Review, Volume 32, No. 5, pp. 1055-1075.

Gilardi, F. (2002) 'Policy credibility and delegation to independent regulatory agencies: a comparative empirical analysis'. Journal of European Public Policy, Volume 9, No. 6, pp. 873-893.

Gilardi, F. (2005) 'The Institutional Foundations of Regulatory Capitalism: The Diffusion of Independent Regulatory Agencies in Western Europe'. Annals of the American Academy of Political and Social Science, Volume 598, No. 1, pp. 84-101.

Gilardi, F. (2008) Delegation in the regulatory state: independent regulatory agencies in Western Europe (Cheltenham, UK; Northampton, MA: Edward Elgar).

Greene, W.H. (2012) Econometric analysis, 7th edition (Boston: Prentice Hall).

Grilli, V., Masciandaro, D. and Tabellini, G. (1991) 'Political and Monetary Institutions and Public Financial Policies in the Industrial Countries'. Economic Policy, Volume 6, No. 13, pp. 341-392.

Guardiancich, I. and Guidi, M. (2015) 'Formal independence of regulatory agencies and Varieties of Capitalism: A case of institutional complementarity?'. Regulation \& Governance, doi:10.1111/rego.12080. 
Guidi, M. (2014) 'Delegation and varieties of capitalism: Explaining the independence of national competition agencies in the European Union'. Comparative European Politics, Volume 12, No. 3, pp. 343-365.

Hanretty, C. and Koop, C. (2013) 'Shall the law set them free? The formal and actual independence of regulatory agencies'. Regulation \& Governance, Volume 7, No. 2, pp. 195-214.

Hausman, J.A. (1978) 'Specification Tests in Econometrics'. Econometrica, Volume 46, No. 6, pp. $1251-1271$.

Honaker, J., King, G. and Blackwell, M. (2011) 'Amelia II: A Program for Missing Data'. Journal of Statistical Software, Volume 45, No. 7, pp. 1-47.

Jappelli, T., Pagano, M. and Bianco, M. (2005) 'Courts and banks: effects of judicial enforcement on credit markets'. Journal of Money, Credit and Banking, Volume 37, No. 2, pp. 223-244.

Jordana, J., Levi-Faur, D. and Fernández i Marín, X. (2011) 'The Global Diffusion of Regulatory Agencies'. Comparative Political Studies, Volume 44, No. 10, pp. 1343-1369.

Karagiannis, Y. (2010) 'Collegiality and the Politics of European Competition Policy'. European Union Politics, Volume 11, No. 1, pp. 143-164.

Kassim, H. and Wright, K. (2009) 'Bringing Regulatory Processes Back In: The Reform of EU Antitrust and Merger Control'. West European Politics, Volume 32, No. 4, pp. 738-755.

Keefer, P. and Stasavage, D. (2003) 'The Limits of Delegation: Veto Players, Central Bank Independence, and the Credibility of Monetary Policy'. The American Political Science Review, Volume 97, No. 3, pp. 407-423.

King, G. and Roberts, M.E. (2014) 'How Robust Standard Errors Expose Methodological Problems They Do Not Fix, and What to Do About It'. Political Analysis, doi:10.1093/pan/mpu015.

Kydland, F.E. and Prescott, E.C. (1977) 'Rules Rather than Discretion: The Inconsistency of Optimal Plans'. The Journal of Political Economy, Volume 85, No. 3, pp. 473-491. 
Levi-Faur, D. (2005) 'The Global Diffusion of Regulatory Capitalism'. Annals of the American Academy of Political and Social Science, Volume 598, No. 1, pp. 12-32.

Lianos, I. (2013) 'Some reflections on the question of the goals of EU competition law'. In I. Lianos and D. Geradin (eds.), Handbook on European Competition Law: Substantive Aspects (Cheltenham, UK: Edward Elgar Publishing), pp. 1-84.

Maggetti, M. (2007) 'De facto independence after delegation: A fuzzy-set analysis'. Regulation \& Governance, Volume 1, No. 4, pp. 271-294.

Maggetti, M. (2009) 'The role of independent regulatory agencies in policy-making: a comparative analysis'. Journal of European Public Policy, Volume 16, No. 3, pp. 450-470.

Maggetti, M. (2012) Regulation in practice: The de facto independence of regulatory agencies (Colchester, UK: ECPR press).

Maggetti, M. (2014) 'The rewards of cooperation: The effects of membership in European regulatory networks'. European Journal of Political Research, Volume 53, No. 3, pp. 480-499.

Majone, G. (1994) 'The rise of the regulatory state in Europe'. West European Politics, Volume 17, No. 3, pp. 77-101.

Majone, G. (1996) 'Temporal Consistency and Policy Credibility: Why Democracies Need NonMajoritarian Institutions'. EUI Working Papers, RSCAS 1996/57.

Majone, G. (1999) 'The regulatory state and its legitimacy problems'. West European Politics, Volume 22, No. 1, pp. 1-24.

Majone, G. (2001) 'Two Logics of Delegation: Agency and Fiduciary Relations in EU Governance'. European Union Politics, Volume 2, No. 1, pp. 103-122.

McChesney, F.S. and Shughart, W.F. (eds.) (1995) The Causes and Consequences of Antitrust: The Public-Choice Perspective (Chicago: University of Chicago Press). 
McCubbins, M.D. and Schwartz, T. (1984) 'Congressional Oversight Overlooked: Police Patrols versus Fire Alarms'. American Journal of Political Science, Volume 28, No. 1, pp. 165-179.

McGowan, L. and Cini, M. (1999) 'Discretion and Politicization in EU Competition Policy: The Case of Merger Control'. Governance, Volume 12, No. 2, pp. 175-200.

Moe, T.M. (1990) 'Political Institutions: The Neglected Side of the Story'. Journal of Law, Economics, \& Organization, Volume 6, Special Issue: Papers from the Organization of Political Institutions Conference, April 1990, pp. 213-253.

Moser, P. (1999) 'Checks and balances, and the supply of central bank independence'. European Economic Review, Volume 43, No. 8, pp. 1569-1593.

OECD (2002) Regulatory Policies in OECD Countries. Available at: http://www.oecdilibrary.org/governance/regulatory-policies-in-oecd-countries_9789264177437-en.

OECD (2012) Recommendation of the Council on Regulatory Policy and Governance. Available at: http://www.oecd.org/governance/regulatory-policy/49990817.pdf.

R Core Team (2013) R: A Language and Environment for Statistical Computing (Vienna, Austria).

Rogoff, K. (1985) 'The Optimal Degree of Commitment to an Intermediate Monetary Target'. The Quarterly Journal of Economics, Volume 100, No. 4, pp. 1169-1189.

Rubin, D.B. (1987) Multiple Imputation for Nonresponse in Surveys (Hoboken, N.J.: John Wiley \& Sons, Inc.).

Thatcher, M. (2002) 'Delegation to Independent Regulatory Agencies: Pressures, Functions and Contextual Mediation'. West European Politics, Volume 25, No. 1, pp. 125-147.

van de Gronden, J.W. and de Vries, S.A. (2006) 'Independent Competition Authorities in the EU'. Utrecht Law Review, Volume 2, pp. 32-66.

van Waarden, F. and Drahos, M. (2002) 'Courts and (epistemic) communities in the convergence of competition policies'. Journal of European Public Policy, Volume 9, No. 6, pp. 913-934. 
Verhoest, K. (2005) 'Effects of Autonomy, Performance Contracting, and Competition on the Performance of a Public Agency: A Case Study'. Policy Studies Journal, Volume 33, No. 2, pp. 235-258.

Verhoest, K., Roness, P.G., Verschuere, B., Rubecksen, K. and MacCarthaigh, M. (2010) Autonomy and Control of State Agencies: Comparing States and Agencies (Houndmills, Basingstoke, Hampshire England; New York: Palgrave Macmillan).

Vining, A.R., Laurin, C. and Weimer, D. (2014) 'The longer-run performance effects of agencification: theory and evidence from Québec agencies'. Journal of Public Policy, doi:10.1017/S0143814X14000245.

Wilks, S. (2005) 'Agency Escape: Decentralization or Dominance of the European Commission in the Modernization of Competition Policy?'. Governance, Volume 18, No. 3, pp. 431-452.

Wilks, S. (2010) 'Competition Policy: Towards an Economic Constitution?'. In H. Wallace, M.A. Pollack and A.R. Young (eds.), Policy-making in the European Union, 6th edition, pp. 133-155 (Oxford; New York: Oxford University Press).

Wilks, S. and Bartle, I. (2002) 'The Unanticipated Consequences of Creating Independent Competition Agencies'. West European Politics, Volume 25, No. 1, pp. 148-172.

Wilks, S. and McGowan, L. (1995) 'Disarming the Commission: The Debate over a European Cartel Office'. JCMS: Journal of Common Market Studies, Volume 33, No. 2, pp. 259-273.

Wonka, A. and Rittberger, B. (2010) 'Credibility, Complexity and Uncertainty: Explaining the Institutional Independence of 29 EU Agencies'. West European Politics, Volume 33, No. 4, pp. 730-752. 


\section{Appendix I: Survey on the formal independence of national competition agencies}

\section{I - The Head of the agency}

1) Does the head of the agency have a fixed term of office?

Yes

No

2) If there is a fixed term, how long is it?

$<4$ years

4 years

5 years

6 years

$>6$ years

3) Who appoints the head of the agency?

One or two ministers

The prime minister

The government collectively

The government and the head of the state

The head of the state

The legislature

The presidents of the chambers

The legislature and the government combined Yes

4) Does the law contain explicit provisions about the dismissal of the head of the agency?

No

5) Can the head of the agency be dismissed?

Can be dismissed for reasons related to policy

Can be dismissed only for reasons not related to policy

Cannot be dismissed

6) Does the law contain explicit provisions about the incompatibility of the head of the agency with other public offices?

Yes

No

7) Can the head of the agency hold other offices in government?

Yes, with permission of the government

Yes, in some cases specified by the law

No

8) Is the term of the head of the agency renewable?

Yes, more than once

Yes, once

No Yes

9) Is political independence a formal requirement for the appointment of the head of the agency?

No 


\section{II - The board of the agency}

1) Does the agency have a board?

Yes

No

2) Do the members of the board of the agency have a fixed term of office? Yes

No

3) If there is a fixed term, how long is it?

$<4$ years

4 years

5 years

6 years

$>6$ years

4) Who appoints the members of the board of the agency?

One or two ministers

The government collectively

The government and the head of the state

The legislature

The presidents of the chambers

The minister consulting the head

The head of the agency Yes

5) Does the law contain explicit provisions about the dismissal of the members of the board of the agency?

No

6) Can the members of the board of the agency be dismissed?

Can be dismissed for reasons related to policy

Can be dismissed only for reasons not related to policy

Cannot be dismissed

7) Does the law contain explicit provisions about the incompatibility of the members of the board of the agency with other public offices?

Yes

No

8) Can the members of the board of the agency hold other offices in government?

Yes, with permission of the government

Yes, in some cases specified by the law

No

9) Is the term of the members of the board of the agency renewable?

Yes, more than once

Yes, once

No

10) Is political independence a formal requirement for the appointment of the members of the board of the agency?

Yes

No

\section{III - Formal relationship of the agency with the parliament and the government}

1) Is the independence of the agency explicitly stated in the law?

Yes

No 
2) What kind of autonomy is the agency granted? [multiple answers possible]

Decisional autonomy

Organizational autonomy

Financial autonomy

3) What are the formal obligations of the agency vis-à-vis the government?

The agency must present reports more than once a year for approval

The agency must present only one annual report that must be approved

The agency must present an annual report for information only

The agency has no formal reporting obligations

4) What are the formal obligations of the agency vis-à-vis the parliament?

The agency must present only one annual report that must be approved

The agency must present an annual report for information only

The agency has no formal reporting obligations

5) Who, other than a court, can overturn an agency's decision?

The government, in specific circumstances

A specialized body

None

6) What is the source of the agency's budget?

Government funding only

Fees levied on firms subjected to the agency's action and government funding

7) Who controls the agency's budget?

The government alone

Both the agency and the government

The accounting office or court

The agency alone

8) Who decides on the agency's internal organization?

Both the agency and the government

The agency alone

9) Who is in charge of the agency's personnel policy?

Both the agency and the government

The agency alone

\section{IV - Other prerogatives of the agency}

1) What are the powers of the competition agency vis-à-vis sectoral agencies in case of competence overlapping?

Sectoral agencies have priority over the competition agency

None has priority: agencies have to coordinate

The competition agency has priority over sectoral agencies

2) Does the agency have the power to set up its own rules of procedure in its activities?

No, never

Only in some activities

Yes, in every activity

3) Does the agency have the power to adopt precautionary measures during investigations?

No, never

Only in some domains of investigation

Yes, in every domain of investigation

4) What kind of sanctions can the agency impose?

It can impose fines

It can impose changes in the undertaking's governance

It can close the undertaking 